\title{
Assessment of How Natural Stand Structure for Narrow Endemic Cedrus brevifolia Henry Supports Silvicultural Treatments for Its Sustainable Management
}

\author{
Elias Milios ${ }^{1, *}$, Petros Petrou ${ }^{2}$, Kyriakos Pytharidis ${ }^{2}$, Andreas K. Christou ${ }^{2}$, Nicolas-George H. Eliades ${ }^{3}$
}

(1) Democritus University of Thrace, Department of Forestry and Management of the Environment and Natural Resources, Pantazidou 193, GR-68200 Orestiada, Greece; (2) Ministry of Agriculture, Rural Development and Environment, Department of Forests, Loukis Akritas 26, CY-1414 Nicosia, Cyprus; (3) Frederick University, Nature Conservation Unit, P.O. Box 24729, CY-1303 Nicosia, Cyprus

*Correspondence: emilios@fmenr.duth.gr

\begin{abstract}
Citation: Milios E, Petrou P, Pytharidis K, Christou AK, Eliades N-GH, 2021. Assessment of How Natural Stand Structure for Narrow Endemic Cedrus brevifolia Henry Supports Silvicultural Treatments for Its Sustainable Management. South-east Eur for 12(1): 21-34. https://doi.org/10.15177/ seefor.21-09.

Received: 16 Feb 2021; Revised: 27 Apr 2021; Accepted: 14 May 2021; Published online: 19 Jun 2021
\end{abstract}

\begin{abstract}
Cedrus brevifolia Henry is a narrow endemic tree species of Cyprus flora. The objectives of this study are to develop silvicultural treatments for the conservation of the species formations based on the stand structure analysis of $C$. brevifolia natural forest and to present the characteristics of the first application of the treatments through silvicultural interventions. Six structural types were distinguished in C. brevifolia formations in the study area located in the state forest of Paphos. For each structural type, six circular plots of approximately $500 \mathrm{~m}^{2}$ were established. In each plot, various measurements and estimations were recorded. Then, silvicultural interventions were applied in the plots of the mixed $C$. brevifolia formations. In the formations of $C$. brevifolia a great number of trees grow in the understory. In the very productive and in the poorly productive sites $C$. brevifolia occurs only in pure formations. The basal area of $C$. brevifolia in pure formations ranges from $19.04 \mathrm{~m}^{2} \cdot \mathrm{ha}^{-1}$ in poorly productive sites to $38.49 \mathrm{~m}^{2} \cdot \mathrm{ha}^{-1}$ in fairly productive sites. Cedrus brevifolia is the most competitive species of the study area as a result of both shade tolerance and the wide range of its site sensitivity behavior. The climax of the study area are the pure stands of $C$. brevifolia having an understory of Quercus alnifolia Poech and a sparse occurrence of Pinus brutia Ten., mainly in moderately productive sites. Forest practice has to, as much as possible, unite species formations in order to create extensive areas of $C$. brevifolia formations.
\end{abstract}

Keywords: Cyprus; shade tolerance; site sensitivity; thinning; marking rules

\section{INTRODUCTION}

Silvicultural interventions for the redistribution of the growing space in order to create certain conditions favor specific individuals or species (Oliver et al. 1996, Milios et al. 2019). In order to develop silvicultural guidelines for the longterm treatment of a forest ecosystem, a basic requirement is a thorough knowledge of the main ecological traits and characteristics of the constituting tree species. The main information needed is the site sensitivity determination (Oliver et al. 1996) of the constituting tree species and the knowledge of their light requirements. This information will be the basis for assessing the competitive ability of the species in the context of the ecosystem in question. Of course, the competitive ability of a species is not a constant trait, since it is also influenced by site productivity and by the competitive ability of the other competing species (Dafis 1986).

Stand height structure analysis combined with stand density and canopy cover data may supply crucial information on the light requirements of the species forming the different stories of the stand. Furthermore, comparative 
stand structure analysis in different site productivity areas is a significant tool in order to determine site sensitivity of the stand constituting species. Site productivity determines competitive superiority between species with different site sensitivity (Oliver et al. 1996), while the existence of trees in various stories in the vertical stand structure depends on the shade tolerance of the tree species (Oliver et al. 1996).

Hence, when the ecology of a tree species is not adequately known or understood, the stand structure analysis of the species formations in sites having different productivity can provide crucial information on its ecological requirements, site sensitivity and competition behavior. One such species is Cedrus brevifolia Henry (Cyprus cedar).

Cedrus brevifolia is a wind-pollinated conifer tree species of the Pinaceae family (Meikle 1977). It is an endemic species of the Cyprus flora, with narrow distribution, since it occurs in a sole population in the area of Paphos Forest. Cedrus brevifolia forest covers an area of 290 ha, which constitutes less than $0.2 \%$ of the high forest vegetation in Cyprus. From 1960 the Department of Forests has been implementing mass plantation of $C$. brevifolia plants at the boundaries of the natural forest of the species, covering today an area of 130 ha (Eliades et al. 2019).

Cedrus brevifolia showed the highest stomatal conductance (Ladjal et al. 2005), while it is characterised by the lowest growth rate, but was found to be the least drought-sensitive among the cedar species (Ducrey et al. 2008). Although C. brevifolia is an island mountainous endemic species with narrow distribution, it revealed a high level of genetic diversity, most likely due to the longterm presence of the species in the mountains of Cyprus (Bou Dagher-Kharrat et al. 2007, Eliades et al. 2011). In addition, the unique population of $C$. brevifolia in Cyprus was not found to be genetically uniform, but rather showed significant genetic structure (genetic differentiation) among identified patches (Eliades et al. 2011). Cedrus brevifolia demonstrates phenotypic variation on its needle color, since two different types are observed, that is, trees with glaucous and trees with green phenotype (Meikle 1977). The conservation status of Cedrus brevifolia was defined in "The Red Data Book of the Flora of Cyprus" (Tsintides et al. 2007), where, based on the IUCN criteria, it was classified as a vulnerable species. In addition, the $C$. brevifolia forest has been coded and included in Annex I of Council Directive 92/43/EEC (The Habitats Directive) as a priority habitat type, namely "9590 *Cedrus brevifolia forests (Cedrosetum brevifoliae)".

The lack of analytical studies on the ecology and stand structure of $C$. brevifolia has led to the absence of interventions in the formations of $C$. brevifolia. Moreover, the lack of ecological knowledge makes it difficult to determine the disturbances which would expose its formations to great risks.

In this context, the objectives of this study are: a) the stand structure analysis of $C$. brevifolia natural formations in the area of the species natural expansion, b) the development of silvicultural treatments for the conservation of the species natural formations, based on the acquired knowledge on the ecology of the species, and c) the presentation of the characteristics of the first application of the treatments through silvicultural interventions.

\section{MATERIALS AND METHODS}

Study Area and the Forest of Cedrus brevifolia in Cyprus As already mentioned, the $C$. brevifolia forest covers an area of 290 ha, located in the top mountains of Paphos Forest (in Troodos mountain range). The species is characterized by limited altitudinal distribution from the upper limits of the meso-Mediterranean to the mid supra-Mediterranean zone (elevation of 900-1400 m above sea level) (Department of Forests 2005). The C. brevifolia forest in Cyprus shows discontinuous distribution (Figure 1), with the main patch of the forest occupying the peak area of Tripylos Mountain, while smaller patches also occur at four surrounding areas, namely: Mavroi Gremoi, Selladi tis Elias, Throni and Exo Milos (Eliades et al. 2019).

The pure C. brevifolia formations cover a total area of 106 ha, while the mixed formations occur in an area of 184 ha (data provided by Department of Forests); in both cases, these formations are scattered. The mixed formations include a wide range of areas in which $C$. brevifolia varies, from a few individuals up to a large number of trees that significantly contribute to the basal area of the formation.

Apart from C. brevifolia, the main species of the mixtures is Pinus brutia Ten. (Calabrian pine), while Quercus alnifolia Poech (golden oak) occurs in the lower stories in both pure and mixed formations (Delipetrou and Christodoulou 2016, personal observation). Moreover, there are areas with groups of $Q$. alnifolia sprouts (multi-stemmed plants) and seedlings - saplings of $C$. brevifolia growing in most cases under the above and side shade of $Q$. alnifolia; which is an evergreen sclerophyllous endemic shrub species of Cyprus with high ecological importance (Tsintides et al. 2002).

In the area where the natural forest of $C$. brevifolia is expanded, in most cases, the $C$. brevifolia formations alternate with formations of $P$. brutia (with the participation of $Q$. alnifolia) and, in some cases, with $Q$. alnifolia formations.

The parent material of the area is igneous rocks (diabase), the soil is slightly acidic and its texture is sandy loam to loam (Gatzogiannis et al. 2010). Soil profiles carried out in the $C$. brevifolia forest detected that the soil depth in the study area ranges from very shallow to very deep, with acidic $\mathrm{pH}$ (5-6.75) (Eliades 2015). The mean annual temperature in the wider area of Tripylos Mountain is $15.78^{\circ} \mathrm{C}$ and the mean annual precipitation $668.7 \mathrm{~mm}$ (data availability for period 1981-2000) (Christou et al. 2001), while the dry period lasts from mid-April up to mid-October (Christou et al. 2001).

\section{Methods}

In order to address the scientific questions of the current study, fieldwork was carried out in 2017. The $C$. brevifolia natural formations were classified in structural types based on two main components: species composition of the formation and productivity of the site.

The species natural formations were classified into two types: pure formations of $C$. brevifolia (PRC), where $C$. brevifolia is the dominant species and composes at least $80 \%$ of the tree basal area, and mixed formations (MXC), where two dominant species exist (C. brevifolia and $P$. brutia). 


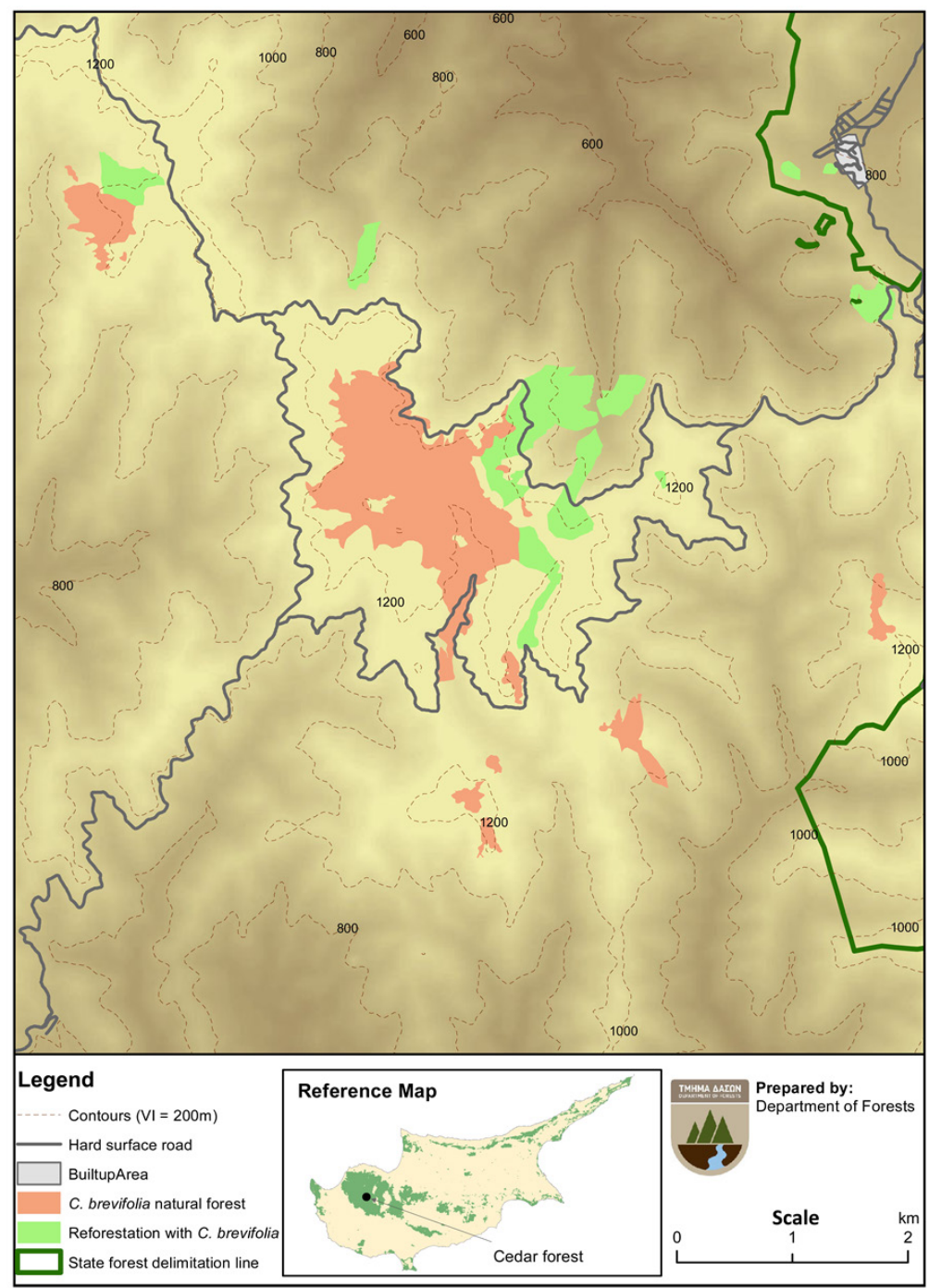

Figure 1. Distribution of C. brevifolia forest on Cyprus.

In addition, the classification of an area in a site productivity category was based on several criteria: soil depth, the form of the terrain (convex or concave) the existence of a stream (water) in the vicinity and the location of the area on the slope (base, middle, upper part, ridge) (Dafis 1986, Barnes et al. 1998, Papalexandris and Milios 2010, Adamopoulos et al. 2009, Stampoulidis et al. 2013, Petrou 2015, Petrou and Milios 2020). The form of the terrain was used as a surrogate of the total depth of the soil (Milios and Papalexandris 2008, Papalexandris and Milios 2010, Adamopoulos et al. 2009, Milios and Papalexandris 2019). Moreover, the location of the area on the slope can be used as a surrogate of the total soil depth (Dafis 1986, Barnes et al. 1998, Adamopoulos et al. 2009, Milios et al. 2012). The actual soil depth was measured (in soil profiles) in the very few cases where there were doubts regarding the classification of an area in a site productivity category.

The above approach of site productivity was based on the assumption that in Mediterranean areas with a dry period in summer, water availability is a significant factor of site productivity. In the same context, soil depth is related to site productivity since soil acts as a water reservoir and supplies the plant roots with water during summer (Dafis 1986, Hatzistathis and Dafis 1989, Papalexandris and Milios 2010). The different site productivity areas where $C$. brevifolia formations grow were easily distinguishable. The very productive sites (SA) are almost exclusively found on the banks of both sides of a local stream. On the contrary, the poorly productive sites (SD) are found only in ridges having narrow widths. In these ridges, soil is almost absent, 
while in most cases rocks (parent material) cover a great part of the terrain surface. The fairly productive sites (SB) occur mainly in concave areas in the middle and the upper part of the slope, while moderately productive sites (SC), are found mainly in the upper part of the slope and in medium width ridges having few or no appearances of rocks and deeper soil than SD. In a few cases, SC are found in the middle of the slope in mostly convex locations. Most of the C. brevifolia formations and the greatest area of the species distribution are found in moderately (SC) and poorly productive sites (SD), while in the very productive sites (SA) the species occurs in continuous areas in almost all cases. The SC covers the largest area in the study area.

Combining the species composition of the formation and productivity of the site, six out of eight different structural types were identified in $C$. brevifolia natural formations:

a) pure C. brevifolia formations found in very productive sites (PRCSA),

b) pure $C$. brevifolia formations found in fairly productive sites (PRCSB),

C) pure C. brevifolia formations found in moderately productive sites (PRCSC),

d) pure C. brevifolia formations found in poorly productive sites (PRCSD),

e) mixed C. brevifolia formations found in fairly productive sites (MXCSB) and

f) mixed C. brevifolia formations found in moderately productive sites (MXCSC).

The mixed structural types comprise only the rather closed formations where $C$. brevifolia constitutes a significant part of the basal area and not the open (having low tree density) mixed formations.

For each structural type six circular plots of approximately $500 \mathrm{~m}^{2}$ (radius of $12.62 \mathrm{~m}$ ) were randomly established in the area where the specific structural type occurs. In total, 36 plots were established. In each plot, the species, the diameter at breast height $(\mathrm{dbh}$ ), (in $\mathrm{cm}$ -precision of one decimal), and the total height, ( $m$ precision of $0.5 \mathrm{~m}$ ) of all living trees with a height of over $1.3 \mathrm{~m}$ were recorded. The diameter measurements were made using diameter tape and the heights were measured using the Haga instrument. For each plot, the clustering of trees to the vertical distribution was done according to three categories: overstory trees, middlestory trees and understory trees (Dafis 1992). Overstory trees were defined as the trees taller than $2 / 3$ of the predominant height (the average height of the tallest 100 trees $\cdot \mathrm{ha}^{-1}-5$ tallest trees in the plot of $500 \mathrm{~m}^{2}$ ). The trees with height equal or more than $1 / 3$ but lower (or equal) than $2 / 3$ of the predominant height were classified as middlestory trees, while those with height lower than $1 / 3$ of the predominant height were classified as understory trees. Noticeably, for Q. alnifolia multi-stem individuals, only the $\mathrm{dbh}$ and the height of the dominant (tallest) stem were recorded.

Finally, for each plot, the canopy cover percentage was visually estimated as a percentage (maximum 100\%) of the plot area, which was covered by the projection of the tree canopy.

\section{Statistical Analysis}

In the comparisons among the heights of the tallest $C$. brevifolia trees of the pure formation structural types (for each structural type the heights of the five tallest trees of each plot were used) the Dunnett T3 was used, since there was no homogeneity of variances. In the comparisons among the basal areas of the pure formations of $C$. brevifolia found in the different site productivity areas, the Duncan test was used.

For the diameter and height distributions of C. brevifolia in each structural type, the Anderson-Darling statistic was used for the examination of the typical distribution (lognormal, exponential, empirical, triangular, Weibull, gamma, normal, beta, uniform) that fits better to them (Milios et al. 2020). The closest fit is provided by the typical distribution having the lowest value of the Anderson-Darling statistic (Anderson and Darling 1954). A p-value is not available in all cases for all distributions that were tested; so the decision for the best-fitted distribution was based on the value of the Anderson-Darling statistic only (IBM 2012). The analyses were conducted using SPSS 21 (IBM 2012).

\section{RESULTS}

As previously mentioned, C. brevifolia forms mixed formations with $P$. brutia and $Q$. alnifolia. Apart from these tree species, woody species such as Platanus orientalis L., Prunus avium L. and Arbutus andrachne L. were also recorded in the established plots and were classified as "other species" (Figure 2 and 3).

In PRCSA from 623 trees.ha-1 of C. brevifolia 393 grow in the understory. In PRCSB, PRCSC and PRCSD the corresponding values are $480-173,346-66$ and $383-53$. In MXCSB from 283 trees ha $^{-1}$ of $C$. brevifolia 137 grow in the understory, while in MXCSC the corresponding values are $200-56$. In the case of Q. alnifolia, in all structural types, the trees grow in the understory and in the middlestory (Table 1).

The height of the tallest $C$. brevifolia trees in PRCSA is higher $(p<0.05)$ than that of the rest of the structural types of pure formations, while the height of the tallest C. brevifolia trees in PRCSD is lower $(p<0.05)$ than the corresponding heights of PRCSA, PRCSB and PRCSC. The height of the tallest $C$. brevifolia trees in PRCSB is higher than the height of the tallest $C$. brevifolia trees in PRCSC (Table 2). The tallest $C$. brevifolia tree measured in a plot has a height of $29 \mathrm{~m}$ and a breast height diameter of $57 \mathrm{~cm}$, while the tree with the largest breast height diameter has a diameter of $109 \mathrm{~cm}$ and a height of $27 \mathrm{~m}$. Both trees grow in plots of PRCSA.

The basal area of $C$. brevifolia in pure formations ranges from $19.04 \mathrm{~m}^{2} \cdot \mathrm{ha}^{-1}$ in poorly productive sites (PRCSD) to $38.49 \mathrm{~m}^{2} \cdot \mathrm{ha}^{-1}$ in fairly productive sites. The maximum canopy cover of C. brevifolia formations is $100 \%$ in very productive (PRCSA) and in fairly productive sites (PRCSB, MXCSB), while in moderately productive sites it is $85 \%$ in PRCSC, and 95\% in MXCS. In poorly productive sites (PRCSD) it is $80 \%$ (Table 1 ). 
Table 1. Structural data of the six structural types in C. brevifolia forest.

\begin{tabular}{|c|c|c|c|c|c|c|}
\hline Species & $\begin{array}{l}\text { Overstory } \\
\left(\text { trees } \cdot \mathrm{ha}^{-1}\right)\end{array}$ & $\begin{array}{l}\text { Middlestory } \\
\left(\text { trees } \cdot \mathrm{ha}^{-1} \text { ) }\right.\end{array}$ & $\begin{array}{l}\text { Understory } \\
\left(\text { trees }^{-} \mathrm{ha}^{-1}\right)\end{array}$ & $\begin{array}{l}\text { Canopy cover range } \\
\text { of all stories (\%) }\end{array}$ & $\begin{array}{c}\text { Basal area } \\
\left(\mathrm{m}^{2} \cdot \mathrm{ha}^{-1}\right)\end{array}$ & $\begin{array}{c}\mathbf{N} \\
\left(\text { trees.ha }^{-1}\right)\end{array}$ \\
\hline \multicolumn{7}{|c|}{ Pure formations in very productive sites (PRCSA) } \\
\hline C. brevifolia & 153 & 77 & 393 & & 36.47 & 623 \\
\hline P. brutia & 0 & 0 & 10 & & 0.0017 & 10 \\
\hline Q. alnifolia & 0 & 0 & 290 & & 0.84 & 290 \\
\hline Other species & 13 & 13 & 90 & & 6.73 & 116 \\
\hline Total & 166 & 90 & 783 & $90-100$ & 44.04 & 1039 \\
\hline \multicolumn{7}{|c|}{ Pure formations in fairly productive sites (PRCSB) } \\
\hline C. brevifolia & 240 & 67 & 173 & & 38.49 & 480 \\
\hline P. brutia & 3 & 0 & 4 & & 0.42 & 7 \\
\hline Q. alnifolia & 0 & 30 & 266 & & 1.25 & 296 \\
\hline Other species & 0 & 0 & 3 & & 0.002 & 3 \\
\hline Total & 243 & 97 & 446 & $90-100$ & 40.16 & 786 \\
\hline \multicolumn{7}{|c|}{ Pure formations in moderately productive sites (PRCSC) } \\
\hline C. brevifolia & 153 & 127 & 66 & & 21.04 & 346 \\
\hline P. brutia & 3 & 10 & 4 & & 0.49 & 17 \\
\hline Q. alnifolia & 0 & 47 & 186 & & 0.34 & 233 \\
\hline Total & 156 & 184 & 256 & $55-85$ & 21.87 & 596 \\
\hline \multicolumn{7}{|c|}{ Pure formations in poorly productive sites (PRCSD) } \\
\hline C. brevifolia & 163 & 167 & 53 & & 19.04 & 383 \\
\hline P. brutia & 3 & 14 & 13 & & 0.06 & 30 \\
\hline Q. alnifolia & 0 & 33 & 110 & & 0.20 & 143 \\
\hline Total & 166 & 213 & 177 & $55-80$ & 19.30 & 556 \\
\hline \multicolumn{7}{|c|}{ Mixed formations in fairly productive sites (MXCSB) } \\
\hline C. brevifolia & 73 & 73 & 137 & & 11.81 & 283 \\
\hline P. brutia & 57 & 26 & 0 & & 12.32 & 83 \\
\hline Q. alnifolia & 0 & 50 & 450 & & 2.23 & 500 \\
\hline Total & 130 & 149 & 587 & $85-100$ & 26.36 & 866 \\
\hline \multicolumn{7}{|c|}{ Mixed formations in moderately productive sites (MXCSC) } \\
\hline C. brevifolia & 97 & 47 & 56 & & 10.85 & 200 \\
\hline P. brutia & 84 & 63 & 50 & & 8.36 & 197 \\
\hline Q. alnifolia & 0 & 100 & 143 & & 1.13 & 243 \\
\hline Total & 181 & 210 & 249 & 70 - 95 & 20.34 & 640 \\
\hline
\end{tabular}

Table 2. Mean height of the tallest $C$. brevifolia trees in the structural types of pure formations.

\begin{tabular}{cccccc}
\hline Structural types of pure formations & $\begin{array}{c}\text { Mean height of the tallest trees } \\
(\mathrm{m})\end{array}$ & S.D. & Min & Max & $\mathbf{n}$ \\
\hline PRCSA & $24.37^{\mathrm{a}}$ & 3.054 & 16.0 & 29.0 & 30 \\
PRCSB & $17.72^{\mathrm{b}}$ & 3.175 & 13.0 & 23.0 & 30 \\
PRCSC & $10.30^{\mathrm{c}}$ & 2.524 & 6.0 & 16.0 & 30 \\
PRCSD & $7.50^{\mathrm{d}}$ & 1.520 & 5.0 & 10.0 & 30 \\
\hline
\end{tabular}

Means are statistically different at $p<0.05$ when they share no common letter. The comparison was made using the Dunnett T3 test, S. D. = standard deviation, $n=$ number of trees, 6 plots $\times 5$ tallest trees $=30$ trees. 

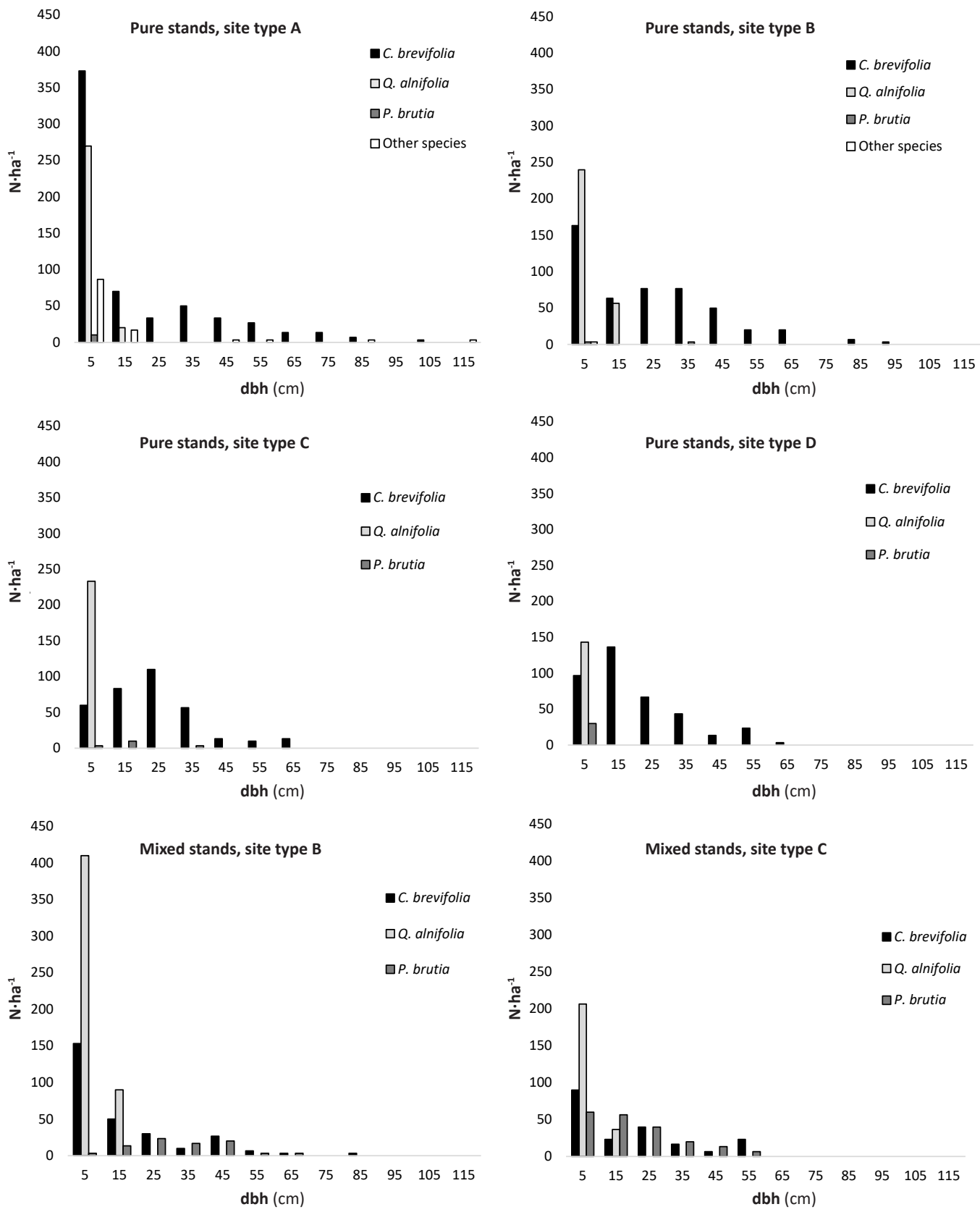

Figure 2. Distributions of tree diameters at breast height ( $\mathrm{dbh}$ ) in the six structural types.

The basal area in PRCSA is not different $(p>0.05)$ compared to that of PRCSB and the basal area in PRCSC is not different $(p>0.05)$ compared to that of PRCSD. However, the basal areas of PRCSA and of PRCSB are higher $(p<0.05)$ than those of PRCSC and of PRCSD (Table 3).
In PRCSA, PRCSB, MXCSB and in MXCSC the diameter class of $5 \mathrm{~cm}$ (the lowest class) has more $C$. brevifolia trees compared to the rest diameter classes (Figure 2), while in PRCSA, PRCSB and MXCSB, the height class of $2 \mathrm{~m}$ (the lowest class) has more $C$. brevifolia trees compared to the rest height classes (Figure 3 ). 

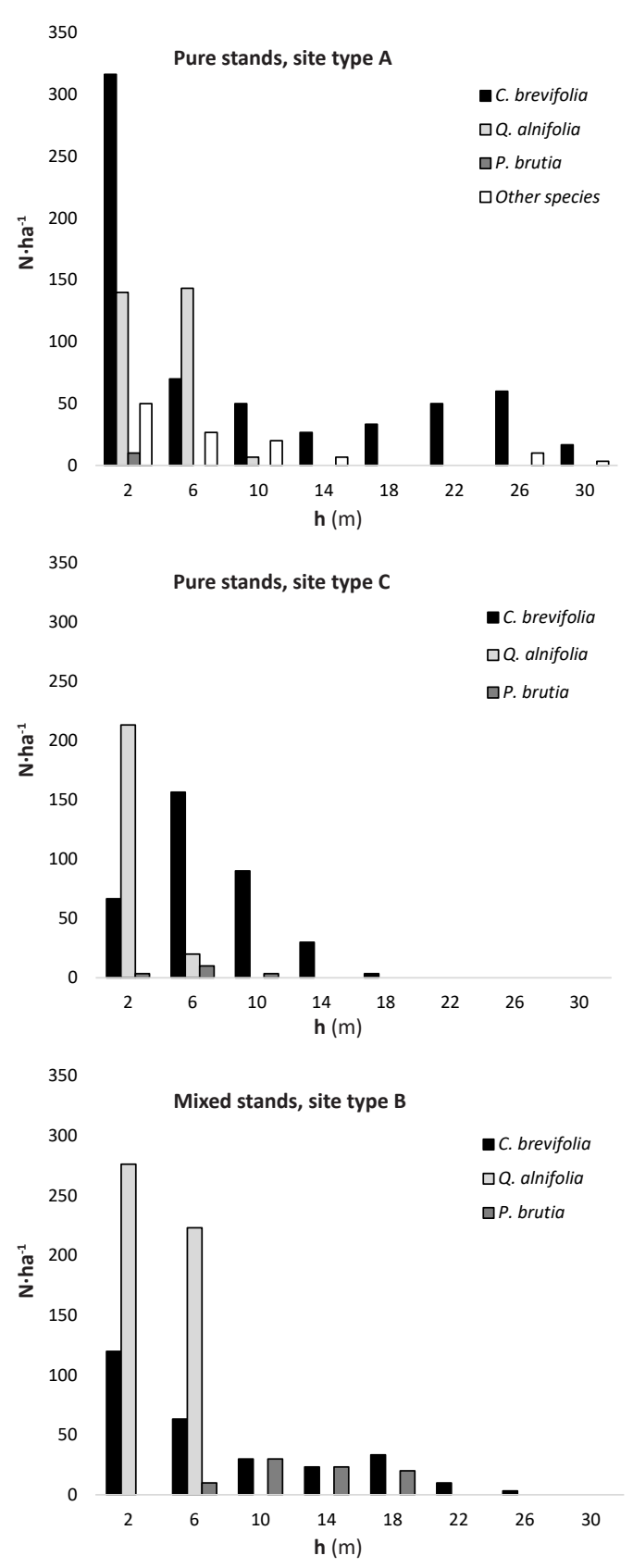

Figure 3. Tree height distributions in the six structural types.

The lognormal distribution fits better in the diameter distributions of $C$. brevifolia in PRCSA and in MXCSB structural types, while the triangular distribution fits better in the diameter distributions of the species in PRCSB and in MXCSC structural types. In the diameter distributions of $C$. brevifolia in PRCSC and in PRCSD the distributions that fit

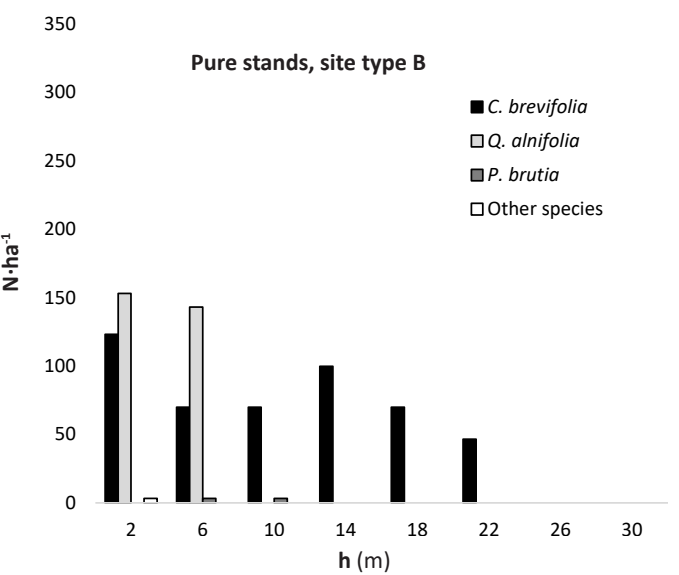

350

300

Pure stands, site type D

250

- C. brevifolia

$\square$ Q. alnifolia

$\square$ P. brutia

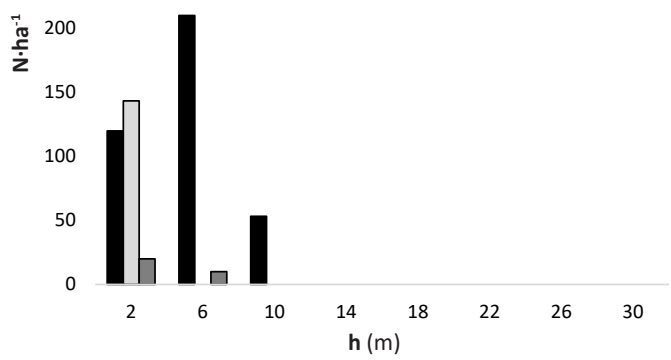

350

Mixed stands, site type C

300

- C. brevifolia

250

$\square$ Q. alnifolia

خ 200

$\square$ P. brutia

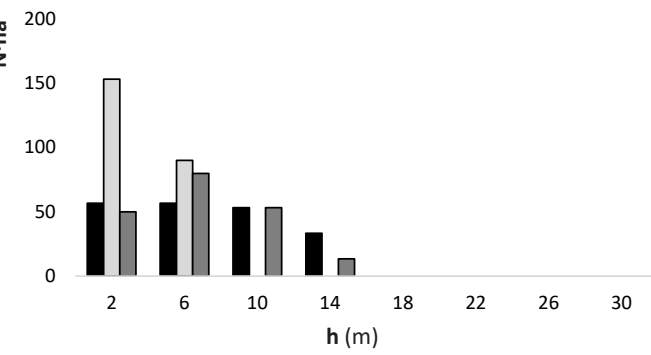

better are the normal and the uniform respectively (Table 4). In the height distributions of the species, the triangular distribution fits better in PRCSD, MXCSB and in MXCSC structural types. In PRCSB and PRCSC the distribution that fits better is the uniform one, while in PRCSA, lognormal distribution fits better (Table 4). 
Table 3. Mean basal area of C. brevifolia trees for plots of each structural type of pure formations.

\begin{tabular}{cccccc}
\hline Structural types of pure formations & Mean basal area $\left(\mathrm{m}^{2}\right)$ & S.D. & Min & Max & $\mathbf{n}$ \\
\hline PRCSA & $1.83^{\mathrm{a}}$ & 0.427 & 1.20 & 2.33 & 6 \\
PRCSB & $1.93^{\mathrm{a}}$ & 0.450 & 1.13 & 2.28 & 6 \\
PRCSC & $1.05^{\mathrm{b}}$ & 0.245 & 0.61 & 1.29 & 6 \\
PRCSD & $0.95^{\mathrm{b}}$ & 0.296 & 0.62 & 1.44 & 6 \\
\hline
\end{tabular}

Means are statistically different at $p<0.05$, when they share no common letter. The comparison was made using the Duncan test, $\mathrm{S}$. D. = standard deviation, $n=$ number of plots.

Table 4. Typical distribution that fits better in the diameter and height distributions of $C$. brevifolia in the different structural types using the Anderson-Darling statistic.

\begin{tabular}{ccc}
\hline Structural type & Typical distribution & A (Anderson-Darling statistic) \\
\hline & Diameter distribution & 0.23 \\
\hline PRCSA & Lognormal & -0.22 \\
PRCSB & Triangular & 0.45 \\
PRCSC & Normal & -0.15 \\
PRCSD & Uniform & 0.27 \\
MXCSB & Lognormal & -0.76 \\
MXCSC & Triangular & 0.42 \\
\hline PRCSA & Height distribution & -0.62 \\
PRCSB & Lognormal & -0.97 \\
PRCSC & Uniform & -1.59 \\
PRCSD & Uniform & -0.64 \\
MXCSB & Triangular & -2.11 \\
MXCSC & Triangular & Triangular \\
\hline
\end{tabular}

\section{DISCUSSION}

In C. brevifolia forest, the diameter distributions of all structural types indicate uneven aged stands (O'Hara 2014) where the individuals with great dimensions are possibly the survivors of previous disturbances, especially in the moderately productive sites (SC) and poorly productive sites (SD) (Milios et al. 2007). On the other hand, in more productive sites ( $S A$ and $S B$ ) the great dimension of many of the large trees might have been the result of the more intense competition in combination with the favorable site conditions (Oliver and Larson 1996).

The differences of the heights of the tallest C. brevifolia trees in the different structural types of pure formations (Table 2) seem to support the classification of sites in relation to their productivity. However, the height of trees that were dominant for their entire life span is used as an index of the growth potential of a site in even-aged stands (Oliver and Larson 1996, Smith et al. 1997). Notably, the height of dominant trees should be compared at the same age. It could be assumed that the trees which comprise the tallest trees in the plots established in the pure formations of each site productivity category were dominant trees in an even-aged group, and at the time of measurement they were of more or less the same age. Under these assumptions, the observed statistically significant differences of the mean height of the tallest $C$. brevifolia trees (Table 2) verify the classification of the areas, where pure formations occur, in the different site productivity categories. This is an indication of correct site productivity classification.

Cedrus brevifolia trees can exhibit large dimension and can create stands with high basal area as in the case of pure formations in the SA and SB. In the PRCSA and PRCSB the basal area of the species is 36.47 and $38.49 \mathrm{~m}^{2} \cdot \mathrm{ha}^{-1}$ respectively (Table 1). These values are higher compared to the value of C. libani basal area referred for stands in Tannourine Cedar Forest Reserve in Lebanon (Bassil et al. 2018), but they are lower than the basal area of pure $C$. atlantica forests in Theniet El Had National Park in Algeria (Sarmoum et al. 2018) and the values of $C$. atlantica basal area of most closed stands in the Moroccan Middle Atlas forests (Linares et al. 2011). In Cyprus, two groups of pure structural types are formed regarding basal area. The first group consists of PRCSA and PRCSB structural types and represents the productive sites, while the second group includes PRCSC and PRCSD structural types representing the less productive sites. The two structural types in each group do not exhibit a difference in basal area $(p>0.05)$, while 
each of the structural types of the productive sites has higher $(p<0.05)$ basal area compared to the structural types of the less productive sites (Table 3).

In the different structural types, the competition regime is differentiated as a result of different tree density and site productivity (Oliver and Larson 1996). This led to differences in tree diameter dimensions and in the form of distributions that consequently led to the great differences observed in the typical distribution that fits better in the diameter distributions of $C$. brevifolia trees in the structural types of the species formations (Table 4). In the case of $C$. brevifolia height distributions of the species formations there are three structural types in which the triangular distribution fits better in their height distribution compared to the other typical distributions that were checked. In two structural types the uniform distribution fits better and in one structural type lognormal distribution fits better (Table 4). The lower variability in the form of height distributions (compared to that of diameter distributions) in the different structural types is due to the factors that determine the height growth of trees. Hence, the competition regime created by the different densities of the formations does not influence significantly the height growth of the dominant trees, as in the case of their diameter. Tree height is mainly influenced and determined mainly by site conditions (Oliver and Larson 1996) and thus the range between the lowest and highest observed height of trees in all sites is reduced.

The shade tolerance of $C$. brevifolia was the decisive factor which determined both diameter and height distributions of the species in the different structural types, since it led to the development of the "robust" lowest diameter and height distribution classes. Cedrus brevifolia exhibits shade tolerance. This is obvious from both the diameter and height distributions of all structural types (Figure 2 and 3). Especially, in PRCSA, PRCSB and MXCSB structural types where the greatest canopy cover percentage is observed, most of the $C$. brevifolia trees of the lowest classes in both diameter and height distributions were established and grew under shade conditions. Moreover, a great percentage of $C$. brevifolia trees grow in the understory of their plot in most structural types (Table 1).

Cedrus brevifolia is more shade-tolerant than its main tree species competitor in the study area, P. brutia. Pinus brutia is a light-demanding (Korakis 2015) and fast-growing species (Kitikidou et al. 2011, Kitikidou et al. 2012). The few $P$. brutia tress with small dimensions (height and diameter) found in PRCSA and PRCSB grow in the edges of their plots (and formations), reaching adequate side (or top) light for their survival. On the other hand, in the PRCSC, PRCSD and MXCSC structural types, the light condition, as a result of the rather low canopy cover percentage created in many locations, allows the establishment and survival of some $P$. brutia trees in the understory (Table 1). In harsh conditions in medium elevation of central Cyprus, P. brutia seedlings can be established and survive at least for one growing season under the facilitation of mature individuals of the species (Petrou and Milios 2012, 2020).

The most significant result of this study is that in the worst site conditions there is only one structural type of the species formations (PRCSD), a pure one, as in the case of the very productive sites (PRCSA). Even though $P$. brutia is a site-insensitive species (Korakis 2015), C. brevifolia is more competitive compared to $P$. brutia in the worst site conditions. Pinus brutia has a very sparse occurrence in poorly productive sites (SD) and this is not the result of unfavorable light conditions, as in the cases of the pure formations of other sites (mainly PRCSA and PRCSB structural types), since the vegetation in the SD formations is more or less sparse in many cases. It seems that $P$. brutia cannot create even very sparse formations in SD. Possibly another reason for the dominance of $C$. brevifolia in SD is the probable larger lifespan of the species compared to $P$. brutia. Thus, $C$. brevifolia is the most competitive species of the study area, owing to both shadetolerance and the wide range of its site sensitivity behavior. This wide range of the site sensitivity may be the outcome of a significant genetic heterogeneity observed among the different site populations of the species (Eliades et al. 2011).

Quercus alnifolia cannot be considered as a strong competitor of $C$. brevifolia, since it is a shrub or small tree reaching a height of up to $10 \mathrm{~m}$ in the plots of this study, while Petrou et al. (2015) measured heights up to $11.60 \mathrm{~m}$ in their study for the construction of site index curves for $Q$. alnifolia in Cyprus. The competition among C. brevifolia and Q. alnifolia trees for light ends when $C$. brevifolia trees reach the height of a few meters.

Regardless of the fact that $Q$. alnifolia grows in the understory exhibiting shade tolerance, it cannot prevent the establishment of $C$. brevifolia trees as it can be concluded from the height and diameter distributions of PRCSA, PRCSB and MXCSB structural types where the greater canopy cover percentage is observed, while many of the understory trees of C. brevifolia had a height of up to $2 \mathrm{~m}$ in all structural types.

Based on the above analysis, the climax of the study area are the pure stands of $C$. brevifolia that have an understory of $Q$. alnifolia and a sparse occurrence of $P$. brutia mainly in moderately productive sites (SC).

\section{Development of Silvicultural Treatments}

Small scale disturbances, which release a small amount of growing space, will not influence the succession in the area. Even in the case of the establishment of a P. brutia individual in the free-growing space, the reoccupation of the growth space from the adjacent $C$. brevifolia trees (mainly in SA and SB mainly and secondly in SC) in combination with the increase in light requirements of the $P$. brutia, as it becomes older and bigger in dimensions (Dafis 1986), will lead to the death of the $P$. brutia tree due to low light availability. In the case of SD, the unfavorable site conditions will not probably allow even the establishment of a P. brutia tree.

Disturbances which release large growing space, killing many trees, like forest fires, act against the dominance of C. brevifolia, since $P$. brutia as a pioneer and bradychorous species (Thanos and Marcou 1991, Spanos et al. 2000, Thanos and Daskalakou 2000, Boydak 2004) will have a competitive advantage. Thus, if no intense disturbances take place in the study area, the succession process will lead to the dominance of $C$. brevifolia in mixed formations and the development of pure C. brevifolia formations. Moreover, C. brevifolia will be established gradually in areas adjacent to species formations and will finally dominate in almost entire study area. However, apart from the prevention of large-scale disturbances like forest fires, forest practice can accelerate succession in the area through the favoring of $\mathrm{C}$. brevifolia.

As it is referred in the study area section, in the area where the natural forest of $C$. brevifolia is expanded, in most cases, the C. brevifolia formations alternate with formations of $P$. brutia 
(with the participation of $Q$. alnifolia) and, in some cases, with Q. alnifolia formations. Forest practice has to unite, as much as possible, species formations in order to create extensive areas of $C$. brevifolia formations. These extensive areas will exhibit high stand structure differentiation as a result of the different age of $C$. brevifolia trees and different site productivity and therefore higher biodiversity (Lindenmayer and Franklin 2002). The treatments proposed to favor the species relate to the removal through cuttings and thinning of individuals of other species (see Figure 4).

Based on the emerged knowledge from this study a workflow was developed, with specific silvicultural treatments for $C$. brevifolia formations. A detailed description of each of the three silvicultural treatment types that have been developed for $C$. brevifolia formations is presented in Figure 4, which also presents the structural types of $C$. brevifolia formations where each silvicultural treatment should be applied.

The silvicultural treatments of Figure 4, are applied through silvicultural interventions (tree cut, thinning etc.). A silvicultural intervention may combine two silvicultural treatments since it can cause different effects in different $C$. brevifolia trees or regeneration plants. For example, from the cutting of a $P$. brutia tree an overstory $C$. brevifolia tree (silvicultural treatment type ii - see Figure 4), as well as two regeneration C. brevifolia plants that are growing under the shade of the cut pine, can be favored simultaneously (silvicultural treatment type i- see Figure 4).

The interventions (treatments) aiming to favor C. brevifolia should not be restricted to only one application. They should be periodically applied. Their characteristics as well as the time of each application (or the need of a new application) should be defined according to structure and competition conditions of the formations. The achievement of even a relatively simple goal, such as the reduction of the intensity of competition, faced by individual $C$. brevifolia trees through the removal of neighbouring competitors belonging to other species, in most cases cannot be accomplished by a single intervention.

The main reasons for that are: (a) the abrupt removal of competition can lead to a drastic change in the conditions of growth for those individuals we want to favor with potentially negative consequences for their growth, even for their survival. Therefore, the redistribution of the growing space should be done gradually with more interventions depending on the prevailing characteristics of competition and (b) the change in competition conditions due to the increment of dimensions of potential competitors. For example, a plant that, in the first intervention, does not compete with the C. brevifolia tree, that is to be favored, over time becomes a strong competitor that should be removed. In addition, the need for periodic interventions arises from the different conditions created by the change in structure characteristics and more generally in competition regime. These changes create new needs for redistribution of the growing space. These needs should be assessed and the necessary measures should be taken each time.

The proposed treatments are referred to the present structure of natural C. brevifolia formations. Potentially, after many decades, in some cases the silvicultural treatments that should be applied to closed natural $C$. brevifolia formations will be moved towards the concepts of the classical silvicultural systems and new silvicultural guidelines should be developed.
Besides, general principles were developed (Box 1) that could be adopted for the sustainable management of C. brevifolia forest, while they are valid for all silvicultural interventions. Hence, in the case of formation structures that have not been analysed or consist of a combination of structures of some of the previously mentioned structural types, the analysed silvicultural treatments, in combination with the general principles which are presented below, provide the information and tools for the application of the proper silvicultural interventions - treatments in order to achieve the goals that were set. The mentioned principles (Box 1) are also valid for the analysed structural types. The term of light intensity is referred to the degree of change of light conditions. Consequently, an intervention is considered as intense when it causes a great increase in light intensity in the forest floor (see below).

Since $C$. brevifolia is the keystone species for the ecosystem in the highest elevations of Paphos Forest (Tripylos Mountain and the neighboring hills), a rational management of the C. brevifolia forest is needed in order to conserve and enhance the ecosystem biodiversity. Along with the proposed silvicultural treatments, forest practice in the area should incorporate the following principles, related to the enhancement of biodiversity, in the silvicultural interventions (Box 1). The proposed principles are based mainly on Lindenmayer and Franklin (2002).

\section{Box 1. General guidelines for silvicultural interventions.}

\section{General principles valid for all silvicultural interventions}

a) Edges: Canopy-formation edges should not retreat or "open" in a great extent as a result of the silvicultural interventions.

b) Ridges - convex areas - not productive sites: Silvicultural interventions in ridges, convex areas and in non-productive sites should be light and applied only where judged essential.

c) Logging debris: Large-scale material $(\mathrm{d}>10 \mathrm{~cm})$ resulting from forestry operations, except for a small percentage, should not remain in the formations to avoid insect damage.

d) Cutting of the top - pruning of trees of various dimensions that compete with C. brevifolia plants: It is a way to reduce competition and it is recommended in cases where, in parallel with competition, a positive influence exists. This cutting can be done and in parallel the canopy density in the micro-locations where $C$. brevifolia plants grow is maintained and the widening of existing gaps is avoided.

e) Low intensity interventions: The interventions in C. brevifolia formations should be of light intensity except in cases where the participation of C. brevifolia trees is low and the objective is to drastically favor the C. brevifolia trees even if a rather wide growing space is released. In these cases, the interventions can be intense. In general, inner (closed) forest conditions should be maintained or disturbed to the smallest extent possible in the closed formations where $C$. brevifolia occurs at a satisfactory rate.

Principles for the conservation and enhancement of biodiversity

a) Retention of standing dead C. brevifolia trees (large dimension dead trees as a priority).

b) Retention of $C$. brevifolia fallen trees on the forest floor.

c) Retention of stumps, having a height of $70-100 \mathrm{~cm}$, originated from the cutting of rather large-dimension trees.

d) Identification and favoring of C. brevifolia individuals having a phenotype with glaucous color of needles.

e) Retention of some living P. brutia trees having large dimensions.

f) Retention of few P. brutia trees in fairly productive sites (SB) and moderately productive sites (SC) (at a later stage, when C. brevifolia dominates in those sites).

g) Favoring of $P$. orientalis individuals, as well as individuals of other broadleaved species, growing mainly inside or on the side banks of the stream in SA, through the cutting of trees, which intensely compete them.

h) Retention of some gaps inside the $C$. brevifolia expansion area. 


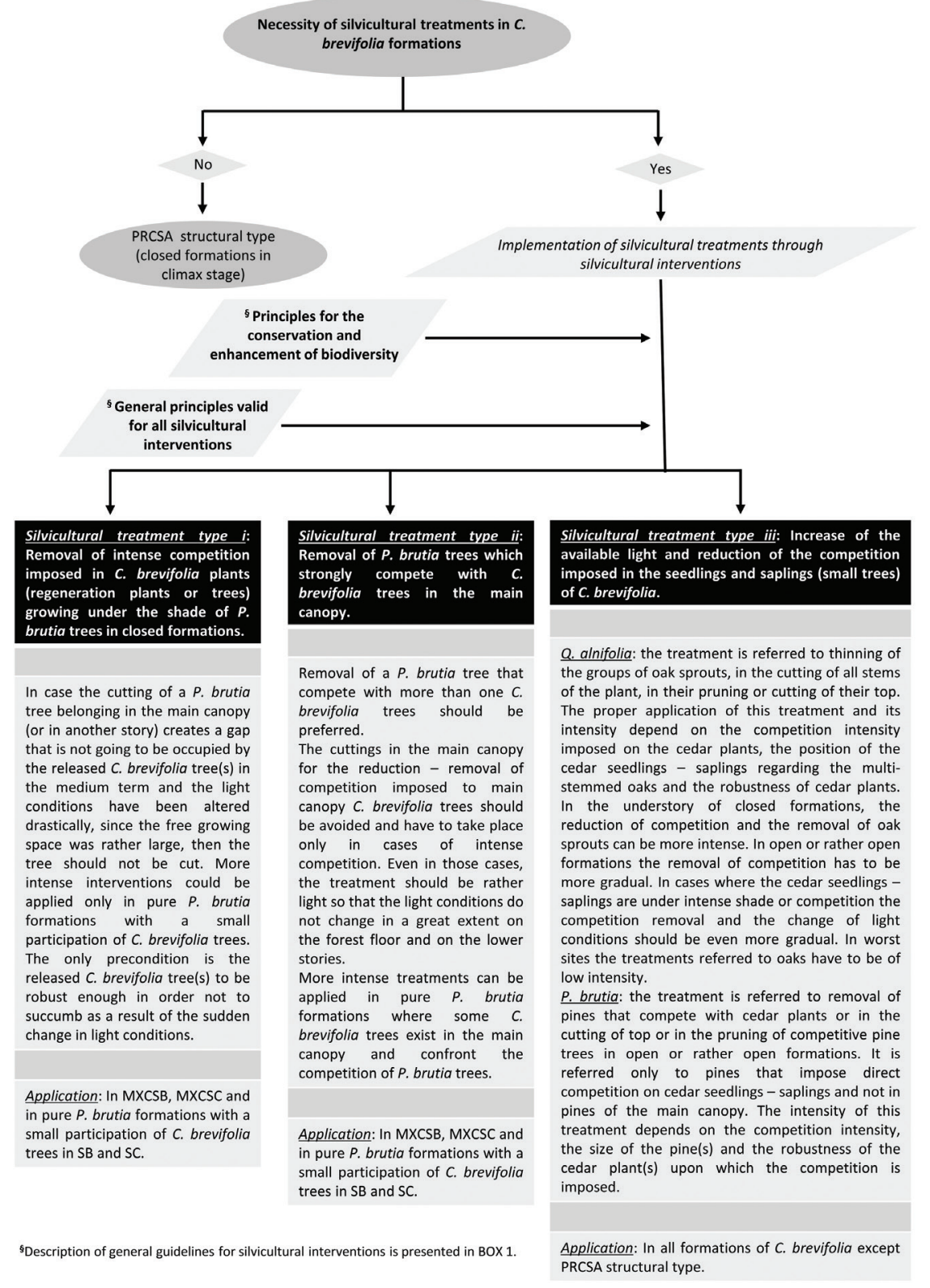

Figure 4. Workflow of silivicultural treatments in C. brevifolia formations.

\section{Application of the Proposed Silvicultural Treatments}

Silvicultural interventions were applied in the plots of the mixed formations (MXCSB, MXCSC) in 2018 (see Box 2). For each silvicultural intervention application, the following data was recorded: a) the type of implemented treatment or treatments, since a cutting of a tree may combine the characteristics of more than one treatment, b) the species of the tree, in which the intervention was applied, and c) the number of the $C$. brevifolia trees and regeneration plants (having a height of between $0.1 \mathrm{~m}$ to $1.3 \mathrm{~m}$ ), which were favored by the intervention.

One improvement developed during the application of the interventions was the killing through girdling (at their base) of large $P$. brutia trees which competed or suppressed C. brevifolia trees. This was done in order to avoid the creation of large gaps, while, at the same time, the competition or the suppression upon $C$. brevifolia plants were removed. 
Box 2. Silvicultural interventions in mixed formations of $C$. brevifolia.

\begin{tabular}{|c|c|c|c|c|}
\hline Structural type & \multicolumn{4}{|c|}{ Silvicultural treatments through silvicultural interventions in C. brevifolia formations } \\
\hline MXCSB & \multicolumn{4}{|c|}{$\begin{array}{l}\text { In total } 18\left(60 \text { ha }^{-1}\right) \text { trees and } 62\left(207 \text { ha }^{-1}\right) \text { regeneration plants of } C \text {. brevifolia were favored by the cut or kill of eight }\left(27 \mathrm{ha}^{-1}\right)(\text { seven } \\
\text { were cut and one was killed) P. brutia trees and the stem thinning (or cut) in } 18\left(60 \mathrm{ha}^{-1}\right) \text { Q. alnifolia trees in the six plots of MXCSB. } \\
\text { In the case of two cut P. brutia trees, C. brevifolia plants were favored in the frame of two silvicultural treatment types. }\end{array}$} \\
\hline MXcsc & \multicolumn{4}{|c|}{$\begin{array}{l}\text { In the plots of MXCSC, } 10\left(33 \mathrm{ha}^{-1}\right) \text { trees and } 54\left(180 \mathrm{ha}^{-1}\right) \text { regeneration plants of } C \text {. brevifolia were favored by the cut or kill of } 14 \\
\left(47 \mathrm{ha}^{-1}\right)\left(13 \text { were cut and one was killed) P. brutia trees and the stem thinning (or cut) of eight }\left(27 \mathrm{ha}^{-1}\right) \text { Q. alnifolia trees. From the }\right. \\
\text { cutting of two P. brutia trees, C. brevifolia plants were favored in the frame of two silvicultural treatment types. }\end{array}$} \\
\hline \multicolumn{5}{|c|}{$\begin{array}{l}\text { Characteristics and results of silvicultural interventions from which the silvicultural treatments were implemented in the plots of mixed C. brevifolia } \\
\text { formations. The numbers in parentheses are referring to values per hectare. }\end{array}$} \\
\hline $\begin{array}{l}\text { Structural } \\
\text { type }\end{array}$ & $\begin{array}{l}\text { Species of the trees to } \\
\text { which the intervention was } \\
\text { implemented }\end{array}$ & $\begin{array}{l}\text { Number of the trees to } \\
\text { which the intervention was } \\
\text { implemented }\end{array}$ & $\begin{array}{l}\text { Number of } C \text {. brevifolia trees } \\
\text { which were favored }\end{array}$ & $\begin{array}{l}\text { Number of } C \text {. brevifolia } \\
\text { regeneration plants which } \\
\text { were favored }\end{array}$ \\
\hline \multirow{2}{*}{ MXCSB } & P. brutia & $8(27)$ & $15(50)$ & $23(77)$ \\
\hline & Q. alnifolia & $18(60)$ & $3(10)$ & $39(130)$ \\
\hline \multirow{2}{*}{ MXCSC } & P. brutia & $14(47)$ & $10(33)$ & $26(87)$ \\
\hline & Q. alnifolia & $8(27)$ & $0(0)$ & $28(93)$ \\
\hline
\end{tabular}

In the plots of mixed formations in SB about $25 \%$ of the P. brutia basal area was removed (trees were cut - killed). This represents approximately $12 \%$ of the total basal area. The corresponding percentages of mixed formations in SC are approximately $16 \%$ (basal area of $P$. brutia) and $7 \%$ (total basal area). These interventions were intense in terms of $P$. brutia basal area removal, but they did not lead to a substantial increase in light intensity in the forest floor. The killing, instead of cutting, of the P. brutia trees worked in that direction.

\section{CONCLUSIONS}

Cedrus brevifolia trees can achieve large dimension and can create stands with high basal area, while they exhibit shade tolerance. Cedrus brevifolia is the most competitive species of the study area as a result of both shade tolerance and the wide range of its site sensitivity behavior. Regardless of the fact that $Q$. alnifolia grows in the understory exhibiting shade tolerance, it cannot prevent the establishment of $C$. brevifolia trees.

The climax of the study area are the pure stands of $C$. brevifolia having and understory of $Q$. alnifolia and a sparse occurrence of $P$. brutia mainly in moderately productive sites. Forest practice should, as much as possible, unite species formations in order to create extensive areas formations - stands of cedar. The treatments proposed to favor the species relate to the removal of individuals of other species.

\section{Author Contributions}

$\mathrm{EM}, \mathrm{PP}, \mathrm{N}-\mathrm{GHE}$ conceived and designed the research; EM and PP designed the methodology in the field; PP and KP processed the data; EM performed data analyses; AKC and N-GHE secured the project funding and supervised the project implementation; EM, PP, $\mathrm{KP}, \mathrm{AKC}, \mathrm{N}-\mathrm{GHE}$ wrote the manuscript.

\section{Funding}

The manuscript is part of the project entitled "Integrated conservation management of priority habitat type 9590* in the Natura 2000 site Koilada Kedron-Kampos" (Acronym: LIFE-KEDROS) a project co-funded by LIFE programme of the European Union (EU); grant number LIFE15 NAT/CY/000850.

\section{Acknowledgments}

The authors wish to thank the staff of Department of Forests (Cyprus), for contributing with fieldwork and map layout.

\section{Conflicts of Interest}

The authors declare no conflict of interest.

\section{REFERENCES}

Adamopoulos S, Milios E, Doganos D, Bistinas I, 2009. Ring width, latewood proportion and dry density in stems of Pinus brutia Ten. Eur J Wood Prod 67: 471-477. https://doi.org/10.1007/s00107009-0345-x.

Anderson T, Darling DA, 1954. Test of Goodness-of-Fit. J Am Stat Assoc 49(268): 765-769. https://doi.org/10.2307/2281537.

Barnes BV, Zak DR, Denton SR, Spurr SH, 1998. Forest ecology. $4^{\text {th }}$ edn. John Wiley \& Sons, Inc., New York, USA, 774 p.
Bassil S, Kattar S, Navarro-Cerrillo RM, Navarrete Poyatos MA, Nemer N, Palacios Rodríguez G, 2018. Stand structure and regeneration of Cedrus libani (A. Rich) in Tannourine Cedar Forest Reserve (Lebanon) affected by cedar web-spinning sawfly (Cephalcia tannourinensis, Hymenoptera: Pamphiliidae). iForest 11(2): 300307. https://doi.org/10.3832/ifor2502-011. 
Bou Dagher-Kharrat M, Mariette S, Lefèvre F, Fady B, Grenier-de March G, Plomion C, Savouré A, 2007. Geographical diversity and genetic relationships among Cedrus species estimated by AFLP. Tree Genet Genomes 3: 275-285. https://doi.org/10.1007/ s11295-006-0065-X.

Boydak M, 2004. Silvicultural characteristics and natural regeneration of Pinus brutia Ten. - A review. Plant Ecol 171: 153-163. https:// doi.org/10.1023/B:VEGE.0000029373.54545.d2.

Christou AK, Hatzikyriakou X, Nikolaou C, 2001. Die-back of Cyprus cedar (Cedrus brevifolia) at Pafos forest. In: Radoglou K (ed) Proceedings of International Conference Forest Research: a challenge for an integrated European approach. Thessaloniki, Greece, pp 269-274.

Dafis S, 1986. Forest ecology. Giahoudis-Giapoulis, Thessaloniki, Greece, 443 p. (in Greek).

Dafis S, 1992. Applied Silviculture. Giahoudis-Giapoulis, Thessaloniki, Greece, 258 p. (in Greek).

Delipetrou P, Christodoulou CS, 2016. Guide for identification and mapping of habitat types of Annex I of the Directive 92/43/EC in Cyprus. Department of Environment, Ministry of Agriculture, Rural Development and Environment, Nicosia, Cyprus, 126 p. (in Greek).

Department of Forests, 2005. Cyprus. In: Merlo, M, Croitoru L (eds) Valuing Mediterranean forests: towards total economic value. CABI Publishing, Wallingford, England, pp 213-225.

Ducrey M, Huc R, Ladjal M, Guehl J-M, 2008. Variability in growth, carbon isotope composition, leaf gas exchange and hydraulic traits in the eastern Mediterranean cedars Cedrus libani and $C$. brevifolia. Tree Physiol 28: 689-701. https://doi.org/10.1093/ treephys/28.5.689.

Eliades N-G, 2015. Report on soil profiles and meteorological data analysis. Technical report, Project DIDAKTOR/0609/13, Frederick University, Nicosia, Cyprus, 19 p. (in Greek).

Eliades N-GH, Gailing O, Leinemann L, Fady B, Finkeldey R, 2011. High genetic diversity and significant population structure in Cedrus brevifolia Henry, a narrow endemic Mediterranean tree from Cyprus. Plant Syst Evol 294: 185-198. https://doi.org/10.1007/ s00606-011-0453-z.

Eliades N-GH, Papageorgiou AC, Fady B, Gailing O, Leinemann L, Finkeldey R, 2019. An approach to genetic resources conservation of peripheral isolated plant populations: the case of an island narrow endemic species. Biodivers Conserv 28: 3005-3035. https://doi.org/10.1007/s10531-019-01812-w.

Gatzogiannis S, Palaskas D, Tsiaras D, Konstantinides P, Tsiourlis G, Kassioumis K, Theofanous S, Sfouggaris A, Georgiakakis P, Poirazides K, Zogaris S, Loubourdis N, Kalapanida M, 2010. Management Plan of the Pafos Forest - Full Edition. Edition of the Project "Preparation of an integrated Management Plan for the Pafos Forest", January 2011, Department of Forests, Nicosia, Cyprus, 376 p. (in Greek).

Hatzistathis A, Dafis S, 1989. Reforestations - Forest nurseries; Giahoudis-Giapoulis: Thessaloniki, Greece, 265 p. (in Greek).

IBM Corp, 2012. Released IBM SPSS Statistics for Windows, Version 21.0. Armonk, NY: IBM Corp.

Kitikidou K, Bountis D, Milios E, 2011. Site index models for calabrian pine (Pinus brutia Ten.) in Thasos island, Greece. Ciência Florestal 21: 125-131. https://doi.org/10.5902/198050982755.

Kitikidou K, Petrou P, Milios E, 2012. Dominant height growth and site index curves for Calabrian pine (Pinus brutia Ten.) in central Cyprus. Renew Sustain Energy Rev 16: 1323-1329. https://doi. org/10.1016/j.rser.2011.10.010.

Korakis G, 2015. Forest botany (e-book). Association of Greek Academic Libraries, Athens, Greece, 619 p. Available online: https://www.ebooks4greeks.gr/dasikh-botanikh-aytofyh-dentrakai-thamnoi-ths-elladas (22 January 2021). (in Greek).

Ladjal M, Huc R, Ducrey M, 2005. Drought effects on hydraulic conductivity and xylem vulnerability to embolism in diverse species and provenances of Mediterranean cedars. Tree Physiol 25: 1109-1117. https://doi.org/10.1093/treephys/25.9.1109.
Linares JC, Taïqui L, Camarero JJ, 2011. Increasing Drought Sensitivity and Decline of Atlas Cedar (Cedrus atlantica) in the Moroccan Middle Atlas Forests. Forests 2: 777-796. https://doi.

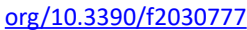

Lindenmayer DB, Franklin JF, 2002. Conserving Forest Biodiversity, A Comprehensive Multiscaled Approach. Island Press, Washington, USA, $351 \mathrm{p}$.

Meikle RD, 1977. Flora of Cyprus, vol 1. The Bentham-Moxon Trust, Royal Botanic Gardens, Kew, UK, 832 p.

Milios E, Kitikidou K, Chatzakis S, Batziou M, 2020. Structure analysis of a lowland grazed Quercus pubescens - Quercus frainetto forest in Northeastern Greece. For Ideas 26(1): 3-14.

Milios E, Kitikidou K, Radoglou K, 2019. New Silvicultural Treatments for Conifer Peri-Urban Forests Having Broadleaves in the Understory - The First Application in the Peri-Urban of Xanthi in Northeastern Greece. South-east Eur For 10(2): 107-116. https:// doi.org/10.15177/seefor.19-16.

Milios E, Papalexandris C, 2008. The influence of shade and site productivity on the seedling density in low elevation stands of Fagus sylvatica L. s.l. located in north-eastern Greece. Lesnicky casopis - Forestry Journal 54(1): 13-20.

Milios E, Papalexandris C, 2019. Height growth of sprouts emerged from small stumps and seed origin saplings under shade, in low elevation Fagus sylvatica L. s.l. stands in Greece. Dendrobiology 82: 1-7. https://doi.org/10.12657/denbio.082.001.

Milios E, Pipinis E, Petrou P, Akritidou S, Kitikidou K, Smiris P, 2012. The Influence of Position and Site on the Height Growth of Young Populus tremula L. ramets in Low Elevation Formations in Northeastern Greece. Not Bot Horti Agrobot Cluj Napoca 40: 302307. https://doi.org/10.15835/nbha4028169.

Milios E, Pipinis E, Petrou P, Akritidou S, Smiris P, Aslanidou M, 2007. Structure and regeneration patterns of the Juniperus excelsa Bieb. stands in the central part of the Nestos valley in the northeast of Greece, in the context of anthropogenic disturbances and nurse plant facilitation. Ecol Res 22: 713-723. https://doi.org/10.1007/ s11284-006-0310-7.

O'Hara KL, 2014. Multiaged Silviculture: Managing for Complex Forest Stand Structures. Oxford University Press, Oxford, UK, 213 p.

Oliver CD, Larson BC, 1996. Forest stand dynamics. John Wiley \& Sons, Inc., New York, USA, 520 p.

Papalexandris C, Milios E, 2010. Analysis of natural Fagus sylvatica L. s.l. regeneration in low elevation stands located in the central part of Evros region in northeastern of Greece. Is sprout origin regeneration significant for species maintenance? Plant Biosyst 44: 784-792. https://doi.org/10.1080/11263504.2010.513867.

Petrou P, 2015. Regeneration, growth and structure of Calabrian pine (Pinus brutia Ten.) stands in the middle elevations of central Cyprus. Phd thesis, Department of Forestry and Management of the Environment and Natural Resources, Democritus University of Thrace, Greece, 215 p. (in Greek).

Petrou P, Kitikidou K, Milios E, Koletta J, Mavroyiakoumos A, 2015. Site index curves for the golden oak species (Quercus alnifolia). Bosque 36:497-503. https://doi.org/10.4067/S071792002015000300016.

Petrou P, Milios E, 2012. Establishment and survival of Pinus brutia Ten. seedlings over the first growing season in abandoned fields in central Cyprus. Plant Biosyst 146: 522-533. https://doi.org/10.10 80/11263504.2011.633574.

Petrou P, Milios E, 2020. Investigation of the factors affecting artificial seed sowing success and seedling survival in Pinus brutia natural stands in middle elevations of central Cyprus. Forests 11: 1349. https://doi.org/10.3390/f11121349.

Sarmoum M, Navarro-Cerrillo RM, Guibal F, Abdoun F, 2018. Structure, Tree Growth and Dynamics of Cedrus atlantica Manetti Forests in Theniet El Had National Park (N-W Algeria). Open J Ecol 8: 432-446. https://doi.org/10.4236/oje.2018.88026.

Smith DM, Larson BC, Kelty MJ, Ashton P, Mark S, 1997. The practice of silviculture. Applied Forest Ecology. John Wiley \& Sons, Inc., New York, USA, $537 \mathrm{p}$.

SEEFOR 12(1): 21-34

https://www.seefor.eu 
Spanos I, Daskalakou E, Thanos CA, 2000. Postfire, natural regeneration of Pinus brutia forests in Thasos island, Greece. Acta Oecol 21: 1320. https://doi.org/10.1016/S1146-609X(00)00107-7.

Stampoulidis A, Milios E, Kitikidou K, 2013. The regeneration of pure Juniperus excelsa Bieb. stands in Pespa National Park in Greece. Šumar list 137(3-4): 163-172.

Thanos CA, Marcou S, 1991. Post-fire regeneration in Pinus brutia forest ecosystems of Samos island (Greece): 6 years after. Acta Oecol 12: 633-642.
Thanos CA, Daskalakou EN, 2000. Reproduction in Pinus halepensis and $P$. brutia. In: Néeman G, Trabaud L (ed) Ecology, biogeography and management of Pinus halepensis and P. brutia forest ecosystems in the Mediterranean. Backhuys, Leiden, Netherlands, pp 79-90.

Tsintides T, Christodoulou CS, Delipetrou P, Georghiou K, 2007. The red data book of the flora of Cyprus. Cyprus Forest Association, Nicosia, Cyprus, $466 \mathrm{p}$.

Tsintides T, Hadjikyriakos GN, Christodoulou CS, 2002. Trees and shrubs in Cyprus. Cyprus Forest Association, Nicosia, Cyprus, 442 p. 